UDC 614.82

\title{
PROBABILISTIC METHOD OF ANALYSIS OF DEGREE OF OPERATING HAZARDS OF TRACTORS ON BASIS OF DETECTION DETAILS
}

\author{
O. V. Voinalovych ${ }^{1}$, O. A. Hnatiuk ${ }^{2}$, L. L. Titova ${ }^{1}$, O. G. Polischuk ${ }^{3}$
}

\author{
${ }^{1}$ National University of Life and Environmental Sciences of Ukraine, Ukraine. \\ ${ }^{2}$ State Labor Service of Ukraine, Ukraine. \\ ${ }^{3}$ Tarashchansky State of Technical, Economic and Legal College, Ukraine. \\ Corresponding authors: voynalov@bigmir.net.
}

Article history: Received: March 2019. Received in the revised form: April 2019. Accepted: May 2019. Bibl. 17, fig. 2, tabl. 0.

Abstract. An analysis of literary sources has shown that the methods used to evaluate occupational risk are mostly attempted to take into account the risk of erroneous actions by workers (operators), neglecting the technical condition of machines and the criticality of accumulation of defects during prolonged operation, which could lead to emergencies and accidents. In the given work the complex method of estimation of occupational risk is offered taking into account the influence of "organizational" and "technical" factors as the basis for forecasting the residual, safe for employees of the resource of machines, in particular method of calculating occupational risks for various types of mechanized work in agriculture using wheeled tractors.

The basic events considered the organizational causes of occupational injuries, in particular violation of the requirements of occupational safety and health by mechanics and job managers, and technical malfunctions of tractor units due to the emergence and spread of operational fractures in responsible parts. The total probability of the basic events should be equal to one.

Probabilities of basic events for organizational reasons were asked according to the known statistical indicators of occupational injuries in the agro-industrial complex, and probability of occurrence of technical malfunctions depending on the duration of operation of the tractor in accordance with an increase in the relative number of cracks in the total mass of the research parts of the tractor.

An example of using the developed method in this paper is the calculation of the probability of a traumatic situation occurring on mechanized works in the agriculture as a result of the sudden lowering of tractor hinged implements, the details of which may cause and spread operational cracks. The calculation is made for cases of subcritical and critical accumulation of operational cracks in the array of investigated critical parts of the tractor.

Key words: professional risk, operational cracks, defectoscopy, mechanized works.

\section{Introduction}

Currently, most scientists and experts in the field of occupational safety argue that the methods of assessment of occupational hazards do not allow objectively evaluate risk performance of work using machines and mechanisms, including those that are of high risk [1-3].

\section{Formulation of problem}

The methods used mostly take into account the risk erroneous actions by workers (machine operators), leaving out the technical condition of the machines and the criticality of accumulation of defects during prolonged operation, which can lead to emergencies and accidents. Therefore, it is important to develop a method for assessing occupational risk taking into account the influence of "organizational" and "technical" factors as the basis for forecasting the residual, safe for workers, the resource of machines.

\section{Analysis of recent research results}

The methods available for assessing occupational (industrial) risk are based on sufficiently close approaches to identifying and comparing risks [4].

Yes, the methods of analyzing a "fault tree" or an "event tree" involve drawing up logic-simulation models (which can be schematically represented as a branching tree) of previously identified possible dangerous factors and their relationships that may cause a dangerous event to occur. The advantages of these methods are the clarity of the presentation of the interconnections of the underlying and intermediate events and the relative ease of calculating the probability of a final dangerous event (if the values of the probabilities of the initial events leading to a malfunction of the work of the technical system and accidents are correctly indicated) [5].

A certain problem of these methods lies in the lack of objectivity in determining the probabilities of the initial events, the failure to take into account the hidden causes and the complexity of representing all interactions in the tree, which may lead to erroneous results of estimating the probability of the occurrence of a final dangerous event [6]. Especially difficult to involve in logic-simulation models are "hidden" failures (malfunctions) machines, which may manifest itself in certain modes of operation [7]. In the 
method of the problem tree, as a rule, only simplified states and operating modes of the machine are analysed: "capable" ("normal") or "not functioning" ("emergency"), which is often insufficient.

Markov analysis [8] is implemented in the form of certain block diagrams of transitions (Markov diagrams), which allow to visualize the process of damage and recovery of the system, taking into account that the sum of all probabilities of the system should be equal to units. But with the increase in the number of elements in the research system, the number of its probable states and transitions between them increases, and thus the error of the final results of the assessment of occupational risk increases [9].

From the analysis of recent studies [10], it can be noted that the use of one or another method to determine the risk of an emergency state of the car (the danger of its operation) is quite subjective [11], since the probability of the basic events in the calculations is based on the conclusions of the expert or group of experts [12], that is, there is a "organizational factor" associated with possible mistaken estimates by experts [13].

\section{Purpose of research}

To develop of a comprehensive method for evaluating occupational risk for the long-term exploitation of mobile agricultural machinery taking into account the influence of organizational (errors of mechanics and job managers) and technical (presence of operational damage of parts of machine parts) factors.

\section{Research results}

In the given work the method of calculation of professional risks for various kinds of mechanized works in agriculture with use of wheeled tractors is offered. The basic events considered the organizational causes of occupational injuries, in particular violation of the requirements of labour protection by mechanics and job managers, and technical malfunctions of tractor units due to the emergence and spread of operational fractures in responsible parts. The total probability of the basic events should be equal to units.

Probabilities of basic events for organizational reasons were asked according to known statistical indicators of occupational injuries in the agro industrial complex [14], and probability of occurrence of technical malfunctions depending on the duration of operation of the tractor in accordance with an increase in the relative number of cracks in the total array of the studied tractor parts [15].

With the help of a specialized portable eddy currents current defectoscope (Fig. 1), the presence of cracks in the details of nodes of more than 50 MTZ-80 (82) tractors with different operating periods (up to 17 years from the date of release) was estimated. On the basis of the received data on the number of detected cracks, kinetic diagrams of the accumulation of cracks in the details of the MTZ-80 (82) knot systems (systems) were constructed and the relative duration of operation was established, after which the intensity of cracking significantly increases. In case of exceeding this value, the probability of sudden destruction of tractor units and the creation of emergency situations on mechanized or transport works with the participation of tractors increases [16].

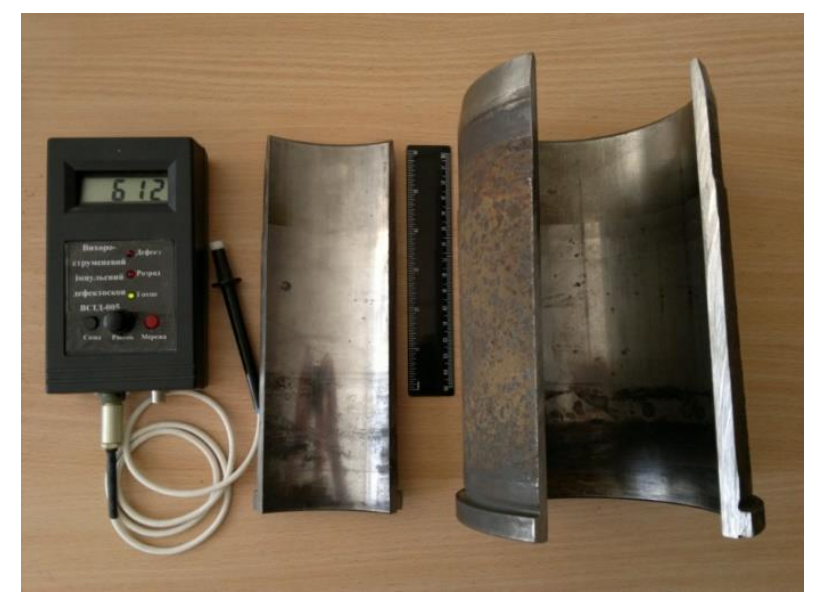

Fig. 1. Portable eddy currents pulse defectoscope (beside to the cut piece of tractor engine sleeve with the main crack on the inner surface).

In this paper, the relative number of cracks in the total array of investigated tractor parts for a certain length of operation was considered as a probabilistic value [17] in the proposed method for calculating occupational risks for various types of mechanized work in agriculture using wheeled tractors. The development of models for creating hazardous situations in the form of a structural scheme (wood) involves identifying connections between the basic and intermediate events (erroneous actions of workers, exploited by defects and failures of technology, adverse external influences of the production environment), forming the main event with a certain risk injuries or accidents. Currently, there is not an exhaustive procedure for creating a tree of events or malfunctions, which would indicate how to logically combine the relationships between the basic and intermediate events, taking into account their significance and the degree of completeness of the analysed set of initial events. There is also a controversial issue to justify the probabilities of the underlying events. It is important to develop logic-simulation models for a large number of various mechanized works in agriculture, which will allow comparing the levels of occupational risk during their implementation in the presence of violations and establish the most significant.

As an example of the use of the developed logic-simulation models in this paper, the calculation of the probability of a traumatic situation occurring in mechanized work in agriculture - as a result of the sudden lowering of tractor hinged implements, in which details of which operational cracks may occur and spread, is presented. The logic-simulation model of the onset of such a traumatic situation is presented in Fig. 2.

In the present work, SAPHIRE computer program [16] was used to analyse the logic-simulation model of the onset of a traumatic situation and to determine the risk of injury to workers who are in the zone of sudden downsizing of tractor hinged implements. The description of separate elements of the developed logic-simulation model is given in the Table 1, which also specifies certain values of the 
basic events, in particular for the subcritical and critical accumulation of cracks in the details of the tractor units (element $\mathbf{J}$ ). The probabilities of basic events in logic-simulation models of hazardous situations are given as those that are consistent with the statistical indicators of occupational injuries in agriculture in Ukraine, averaged over the past 5 years. They were taken from the annual statistical bulletin "Traumatism in the production" of the State Statistics Service of Ukraine.
The calculation was performed for two lifetime tractors, namely 6 and 13 years old when the relative number of cracks in the overall array studied Tractor amounted to 0.2 and 0.45 .

Changes in occupational risk indicators for a certain element of the logic-simulation model of a dangerous situation show how the risk of injury increases in the case of an intermediate and full impact of a dangerous factor (Table 2).

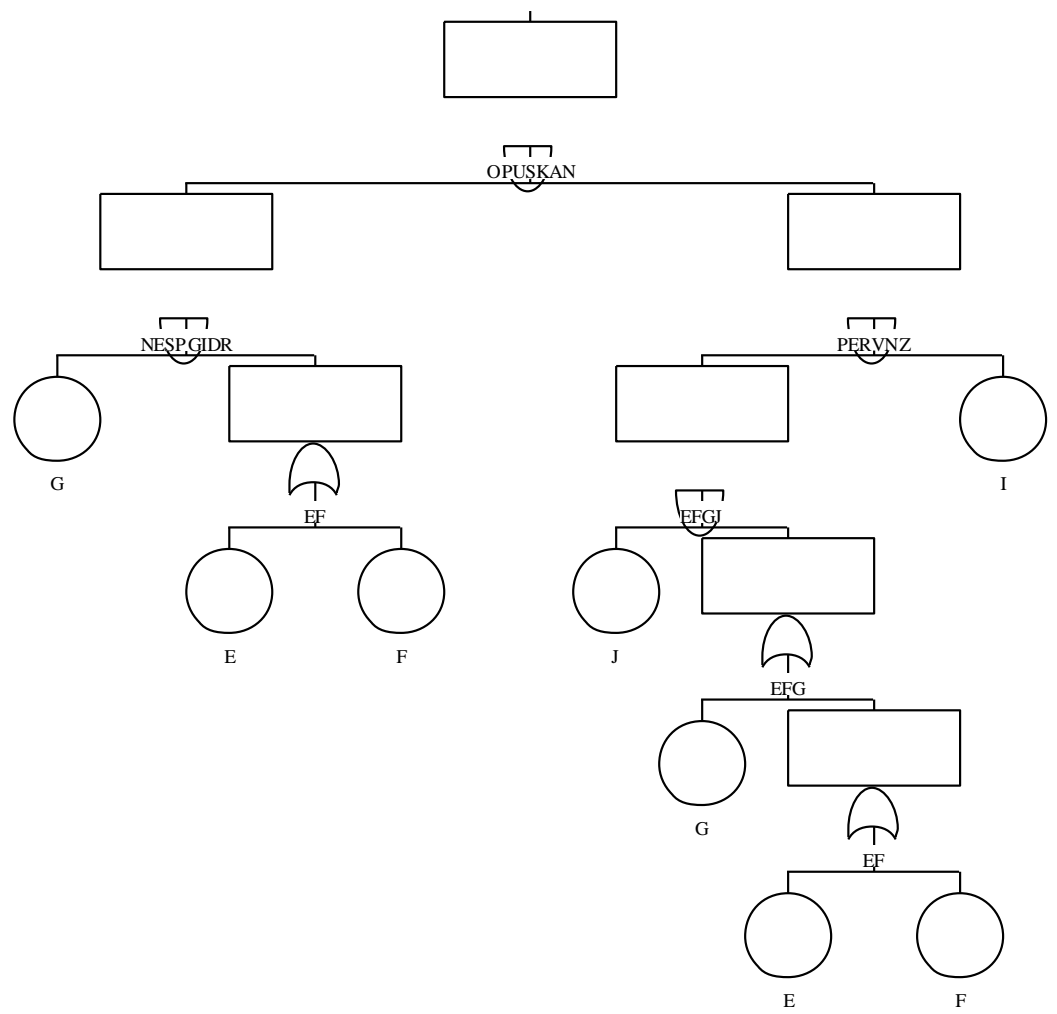

Fig. 2. Block diagram of the logic-simulation model of a dangerous situation "the sudden lowering of tractor hinged guns".

Table 1. Description of elements of the logic-simulation model of a dangerous situation.

\begin{tabular}{|c|l|c|}
\hline $\begin{array}{c}\text { Designation of ele- } \\
\text { ments (basic and in- } \\
\text { termediate events) }\end{array}$ & \multicolumn{1}{|c|}{ Description of elements (basic and intermediate events) } & $\begin{array}{c}\text { Default } \\
\text { probability } \\
\text { of basic } \\
\text { events }\end{array}$ \\
\hline E & The agrarian enterprise has not created a labour protection service & 0,15 \\
\hline F & $\begin{array}{l}\text { The company does not establish effective work on occupational safety (in partic- } \\
\text { ular, it does not conduct training and instruction on occupational safety issues, } \\
\text { does not control the technical condition of machinery and equipment from the } \\
\text { standpoint of their safety, do not assess the professional suitability of workers, } \\
\text { etc.) }\end{array}$ & 0,25 \\
\hline EF & Control over occupational safety at the enterprise is considered unsatisfactory & \\
\hline G & Insufficient skill level and skills of mechanics & 0,15 \\
\hline EFG & Violation of normative terms of technical inspection and maintenance of tractors & \\
\hline J & The presence of cracks in the details of the site & $0,2 / 0,45$ \\
\hline EFGJ & Operation of a tractor with a defective hinged system & 0,25 \\
\hline I & $\begin{array}{l}\text { The necessity of carrying out technological operations and inspections to elimi- } \\
\text { nate defects in the work of the hinged system or other reasons that make the } \\
\text { worker (machine operator) remain in the danger zone of lowering the tractor's } \\
\text { hinged implements }\end{array}$ & \\
\hline PERVNZ & Occupation of a worker in a dangerous area of lowering a hinged gun & \\
\hline OPUSKAN & Sudden lowering of the hinged gun & \\
\hline
\end{tabular}


Table 2. Risk Indicators for the logic-simulation model of a dangerous situation "the sudden lowering of tractor hinged guns".

\begin{tabular}{|c|c|c|c|}
\hline $\begin{array}{c}\text { Dangerous factor (action, } \\
\text { event, situation) }\end{array}$ & $\begin{array}{c}\text { Conditional characteristic of a dangerous } \\
\text { factor - the relative number of cracks in the } \\
\text { total array of investigated tractor parts }\end{array}$ & $\begin{array}{c}\text { Calculated } \\
\text { risk score, } \mathrm{P}\end{array}$ & $\begin{array}{c}\text { Change in the risk indi- } \\
\text { cator in the presence of } \\
\text { danger, times }\end{array}$ \\
\hline $\begin{array}{c}\mathrm{J} \text { (presence of cracks in } \\
\text { node details) }\end{array}$ & 0,2 & $2,998 \cdot 10^{-3}$ & - \\
\cline { 2 - 4 } & 0,45 & $6,739 \cdot 10^{-3}$ & 2,25 \\
\hline
\end{tabular}

From Table 2 shows that the risk of injury to workers as a result of the sudden lowering of the tractor's hinged gauge increases 2,25 times after reaching the critical fracture depth of the operation cracks in the details of the tractor hinged system.

The proposed method of assessment of danger prolonged use of mobile agricultural machinery can be used to develop professional risk classifier for mechanized agriculture. In contrast to the method of expert assessments and other qualitative methods of assessment of occupational hazards developed a quantitative method based on objective ratios that correlate to statistics of occupational injuries in storage and data on operational damage in a common set of parts unit. Especially important is not only the absolute values of statistical indicators, but their change in relative terms, as illustrated by the Table 2 .

However, the proposed method will provide an objective assessment of changing occupational risk only when used defectoscopic modern equipment that allows you to find hidden defects (cracks) which can lead to sudden failure equipment and emergency situations that lead to accidents. Visual inspection applied to detection of visible damage and cracks, and instrumental control with a ruler or calipers to determine changes configuration and size (curved, torsion beating, warping, not perpendicular and other violations of mutual accommodation and surfaces of the axes) must recognize insufficient to detect all potentially dangerous defects in the array of parts agricultural machine.

The data on the increase of professional risk mechanized work can be used how for about acceptable level of risk using mobile agricultural machinery operating with damaged parts and structural elements, and for predicting the residual life of the unit after prolonged use.

The calculation results to assess the importance to create an emergency (dangerous) situation as machine operators erroneous actions of his level of training and physical and psychological state, and technological factors. Analyzing the importance of technical factors in the mechanism of dangerous situations, it is necessary to distinguish its two components - the constructional and operational directly affect the technical safety of the machine. Therefore, it is necessary to implement the logic simulation techniques at the design stage and testing of agricultural machinery, considering these methods as an important tool for reducing occupational risk mechanized.

\section{Conclusions}

1. A comprehensive method for assessing occupational risk for long-term exploitation of mobile agricultural machinery has been developed, taking into account the organizational (mechanics and machinery mistakes) and technical (presence of operational damages of parts) factors. It has been shown that the construction of models of hazardous production situations should be based on the isolation of one (main) event, a truly dangerous situation and many prerequisites - erroneous actions of workers, technological failures and unfavourable external influences of the production environment.

2. Results of the calculation of the elements of the logic-simulation model of the process of traumatic situation allow to estimate the risk of injury to workers who operate mobile agricultural machinery, in particular as a result of accumulation of operational damage in the responsible parts of the nodes. The obtained values, which correspond to unacceptable occupational risk, should be the basis for observance of normative terms of passing of maintenance of mobile equipment and replacement of damaged parts.

\section{References}

1. Bochkovskii A. A. (2016). Theoretical aspects of the universalization of occupational risk assessment in occupational safety management systems. Collection of scientific works Bulletin of the LDU. Safety. No 14. 134-150.

2. Predko V. O., Mishenina O. S., Strilets V. M. (2014). Determining of the boundaries of applying existing methods for calculating of occupational risk. Problems of Emergencies: Collection of scientific works. 2014. Issue 19. 98-106.

3. Khrupachev A. G. (2011). Occupational risk. Theory and practice of calculation, Ed. A. G. Khrupacheva, A. A. Khadartseva. Tula. Publishing house of Tula State University. 2011. 330.

4. Malyshev V. A., Nikitenko Yu. V. (2013). Generalized methods of managing of technogenic risks in the enterprise. Bulletin of the Voronezh Institute of High Technologies. 2013. No 2. 129-134.

5. Kozlitin A. M. (2009). Theory and methods of risk analysis of complex technical systems: monograph. Saratov. Sarat. state. tech. university. 200.

6. Piktushanskaya T. E. (2009). Experience in using of the mathematical model in assessing a posteriori occupational risk. Occupational medicine and industrial ecology. No 12. 41-44.

7. Ivanov V. I., Gulyaeva O. G. (2009). Assessment of suitability for operation and monitoring of industrial risks at hazardous production facilities. Occupational safety in industry. No 5. 79-81.

8. Timofeeva S. S. (2016).. Modern methods for assessing of occupational risks and their significance in the OSH management system. XXI century. Technospheric security. No 1(1). 14-24.

9. Petrovsky E. A., Gagina M. V. (2015). Application of methods of Markov processes for modeling of reliability 
and risk of oil and gas equipment. Proceedings of the International Symposium "Reliability and Quality": 2 vol. Penza: PSU. Vol. 2. 312-313.

10. Meltser A. V., Kiselev A. V. (2009). Hygienic rationale for combined risk assessment models. Occupational medicine and industrial ecology. No 4. 1-5.

11. Gogitashvili G. G., Kaminsky V. F., Lapin V. M. and others (2010).. Assessment of occupational risk in Ukrainian agricultural production. Bulletin of Agrarian Science. No 8. 53-55.

12. Agnieszka Buczaj, Leszek Solecki. (2010). Occupational risk assessment in agriculture. Lublin. Institute of medicine. 351.

13. Averin G. V., Moskalets V. M. (2008). Analysis of the state and safety of high-risk facilities in the metallurgical industry. Bulletin of Donetsk University. Series A. Natural Sciences. No 1. 324-332.

14. Voinalovich O. V. (2014). Analysis of the causes of accidents in agriculture in recent years. Problems of Occupational Safety, Industrial and Civil Security: A collection of materials for the Tenth All-Ukrainian Scientific and Methodological Conference (with the participation of students), Kyiv, May 13-15, NTUU "KPI". 33-38.

15. Polyansky O. S., Voinalovich O. V., Motrich M. M. (2018). Estimation of the risk of exploitation of agricultural aggregates according to the data of defectoscopy. Bulletin of the Kharkiv National Technical University of Agriculture. Petro Vasilenko. Issue 190. 185192.

16. Begun V. V. (2009). Security monitoring based on the analysis of probabilistic structural and logical production models. Modeling and Information Technologies: Sb. sciences works. Kiev. IPEM. G. E. Pukhov. Issue 52. 1726.

17. Hnatiuk O. A., Begun V. V. (2012). Modeling of the influence of dangerous industrial factors on the safety indices of machine-tractor aggregates in the conditions of agro-industrial production by probabilistic methods. Techno-technological aspects of development and testing of new technology and technologies for agriculture in Ukraine: a collection of scientific works. DNU UkrNDIPVT after L. Pogorelogo. Vol. 16 (30). T. 2. 81-96.

\section{Список літератури}

1. Бочковський A. А. Теоретичні аспекти універсалізації оцінки професійного ризику в системах управління охороною праці. Збірник наукових праць Вiсник ЛДУ. БЖД. 2016. № 14. С. 134-150.

2. Предко В. О., Мішеніна О. С., Стрілецьв В. М. Визначення границь застосування існуючих методів розрахунку професійного ризику. Проблеми надзвичайних ситуацій: Збірка наукових праць. 2014. Випуск 19. С. $98-106$.

3. Хрупачев А. Г. Профессиональный риск. Теория и практика расчета. Под ред. А. Г. Хрупачева, А. А. Хадарцева. Тула: Изд-во ТулГУ. 2011. 330 с.

4. Мальшев В. А., Никитенко Ю. В. Обобщенная методика управления техногенными рисками на предприятии. Вестник Воронежского института высоких технологий. 2013. № 2. С. 129-134.
5. Козлитин А. М. Теория и методы анализа рисков сложных технических систем: монография. Саратов: Сарат. гос. техн. ун-т. 2009. 200 с.

6. Пиктушанская T. Е. Опыт использования математической модели при оценке апостериорного профессионального риска. Медицина труда и промышленная экология. 2009. № 12. С. 41-44.

7. Иванов В. И., Гуляева О. Г. Оценка пригодности к эксплуатации и мониторинг промышленных рисков на опасных производственных объектах. Безопасность труда в промышленности. 2009. № 5. С. 79-81.

8. Тимофеева C. C. Современные методы оценки профессиональных рисков и их значение в системе управления охраной труда. XXI век. Техносферная безопасность. 2016. № 1(1). С. 14-24.

9. Петровский Э. А., Гагина М. В. Применение методов Марковских процессов для моделирования надежности и риска оборудования нефтегазового комплекса. Труды Международного симпозиума «Надежность и качество»: в 2 т. Пенза: ПГУ. 2015. 2 т. С. 312 313.

10. Мельцер А. В., Киселев А. В. Гигиеническое обоснование комбинированных моделей оценки профессионального риска. Медицина труда и промышленная экология. 2009. № 4. С. 1-5.

11. Гогіташвілі Г. Г., Камінський В. Ф., Лапін B. $M$ та ін. Оцінювання професійного ризику в галузях сільськогосподарського виробництва України. Вісник аграрної науки. 2010. № 8. С. 53-55.

12. Ocena ryzyka zawodowego w rolnictwie. Praca zbiorowa pod redakcja Agnieszki Buczaj, Leszka Soleckiego. Lublin, Instytut medycyny wsi. 2010. 351 p.

13. Аверин Г. В., Москалеи В. М. Анализ состояния и безопасности объектов повышенной опасности металлургической отрасли. Вестник Донецкого университета. Серия А. Естественные науки. 2008. № $1.324-332$.

14. Войналович О. В. Аналіз причин нещасних випадків у сільському господарстві за останні роки. Проблеми охорони праці, промислової та цивільної безпеки: Збірник матеріалів Десятої Всеукраїнської науково-методичної конференції (з участю студентів), м. Київ, 13-15 травня 2014 р. К.: НТУУ “КПІ”. 2014. С. $33-38$.

15. Полянський О. С., Войналович О. В., Мотрич $M . M$. Оцінення небезпеки експлуатації сільськогосподарських агрегатів за даними дефектоскопії деталей. Вісник Харківського національного технічного університету сільського господарства імені Петра Василенка. 2018.

Випуск 190. С. 185-192.

16. Бєзун В. В. Моніторинг безпеки на основі аналізу ймовірнісних структурно-логічних моделей виробництва. Моделювання та інформаційні технології: зб. наук. праць. К.: ІПМЕ ім. Г.С. Пухова. 2009. Вип. 52. C. 17-26.

17. Гнатюк $O$. A., Бєгун $B$. В. Моделювання впливу небезпечних виробничих чинників на показники безпеки машинно-тракторних агрегатів в умовах агропромислового виробництва імовірнісними методами. Техніко-технологічні аспекти розвитку та випробування нової техніки і технологій для сільського гос- 
подарства України: збірник наукових праць. ДНУ УкрНДІПВТ ім. Л. Погорілого. Дослідницьке. 2012. Вип. 16 (30). Кн. 2. С. 81-96.

\section{ЙМОВІРНІСНИЙ МЕТОД АНАЛІЗУ СТУПЕНЮ НЕБЕЗПЕКИ ЕКСПЛУАТАЦІЇ ТРАКТОРІВ НА ЗАСАДАХ ДАНИХ ДЕФЕКТОСКОПІЇ ДЕТАЛЕЙ О. В. Войналович, О. А. Гнатюк, Л. Л. Тітова, О. Г. Полішук}

Анотація. Виконаний аналіз літературних джерел показав, що використовувані методи оцінення професійного ризику здебільшого намагаються врахувати ризик помилкових дій працівників (операторів), залишаючи поза увагою технічний стан машин та критичність накопичення дефектів протягом тривалої експлуатації, що може призвести до аварійних ситуацій та нещасних випадків. У даній роботі запропоновано комплексний метод оцінення професійного ризику з урахуванням впливу «організаційного» та «технічного» чинників, як основи для прогнозування залишкового, безпечного для працівників ресурсу машин, зокрема. методику розрахунку професійних ризиків для різних видів механізованих робіт у сільському господарстві 3 використанням колісних тракторів.

Як базові події розглядали організаційні причини виробничого травматизму, зокрема порушення вимог охорони праці механізаторами і керівниками робіт, та технічні несправності вузлів тракторів, зумовлені виникненням і поширенням експлуатаційних тріщин у відповідальних деталях. Загальна сума ймовірностей базових подій має дорівнювати одиниці.

Ймовірності базових подій, що відповідають організаційним причинам, задавали згідно з відомими статистичними показниками виробничого травматизму в агропромисловому комплексі, а ймовірності настання технічних несправностей - залежно від тривалості експлуатації трактора відповідно до збільшення відносної кількості тріщин у загальному масиві досліджуваних деталей трактора.

Як приклад використання розробленого методу в даній роботі представлено розрахунок ймовірності настання травмонебезпечної ситуації на механізованих роботах - внаслідок раптового опускання навісного знаряддя трактора, в деталях якого можуть виникнути і поширитися експлуатаційні тріщини. Розрахунок виконано для випадків докритичного і критичного накопичення експлуатаційних тріщин у масиві досліджуваних відповідальних деталей трактора.

Ключові слова: професійний ризик, експлуатаційні тріщини, дефектоскопія, механізовані роботи.

\section{ВЕРОЯТНОСТНЫЙ МЕТОД АНАЛИЗА СТЕПЕНИ ОПАСНОСТИ ЭКСПЛУАТАЦИИ ТРАКТОРОВ НА ОСНОВЕ ДАННЫХ ДЕФЕКТОСКОПИИ ДЕТАЛЕЙ \\ А. В. Войналович, О. А. Гнатюк, Л. Л. Титова, А. Г. Полищук}

Аннотация. Выполненный анализ литературных источников показал, что используемые методы оценки профессионального риска в основном пытаются учесть риск ошибочных действий работников (операторов), оставляя без внимания техническое состояние машин и критичность накопления дефектов при длительной эксплуатации, что может привести к аварийным ситуациям и несчастным случаям. В данной работе предложен комплексный метод оценки профессионального риска с учетом влияния «организационного» и «технического» факторов, как основы для прогнозирования остаточного, безопасного для работников ресурса машин, в частности. методику расчета профессиональных рисков для различных видов механизированных работ в сельском хозяйстве с использованием тракторов.

Как базовые события рассматривали организационные причины производственного травматизма, в том числе нарушения требований охраны труда механизаторами и руководителями работ, и технические неисправности узлов тракторов, обусловленные возникновением и распространением эксплуатационных трещин в ответственных деталях. Общая сумма вероятностей базовых событий должна быть равна единице.

Вероятности базовых событий, соответствующих организационным причинам, задавали согласно известным статистическим показателям производственного травматизма в агропромышленном комплексе, а вероятности наступления технических неисправностей - в зависимости от продолжительности эксплуатации трактора в соответствии с увеличением относительного количества трещин в общем массиве исследуемых деталей трактора.

В качестве примера использования разработанного метода в данной работе представлен расчет вероятности наступления травмоопасной ситуации на механизированных работах - в результате внезапного опускания навесного устройства трактора, в деталях которого могут возникнуть и распространиться эксплуатационные трещины. Расчет выполнен для случаев докритического и критического накопления эксплуатационных трещин в массиве исследуемых ответственных деталей трактора.

Ключевые слова: профессиональный риск, эксплуатационная трещина, дефектоскопия, механизированные работы.

Voinalovych O. V. ORCID 0000-0002-9321-2672.

Hnatiuk O. A. ORCID 0000-0002-6866-3674.

Titova L. L. ORCID 0000-0001-7313-1253.

Polischuk O. G. ORCID 0000-0002-8435-2876. 